Ewa KęBŁOWSKa-ŁaWNiCZAK

Uniwersytet Wrocławski

\title{
Brexit on Stage: Two Verbatim Projects in Progress
}

Brexit triggered a widening spectrum of responses from theatre writers, critics and directors. Moreover, it refocused the audience's response to both current plays and revivals. And so the 2018 revival of George Bernard Shaw's Saint Joan: A Chronicle Play in Six Scenes and an Epilogue became for the post-Brexit audience a story of regained sovereignty and patriotism rather than individual responsibility. A year after the vote, while announcing the launch of a new popular drama series entitled Brexit Shorts: Dramas from a Divided Nation, a collection of monologues addressing current headline topics, GNM's press office ${ }^{1}$ referred to Britain's decision to leave the $\mathrm{EU}$ as the most significant event since WW2.

The aftermath of the vote, GNM's press office observes, has been marked by a still continuing series of "shockwaves" (GNM 2017). As it has been estimated that a vast majority of the "creatives" in the United Kingdom voted for Remain, their response to the results of the Referendum was perhaps unsurprisingly emotional and, to use one of the Brexit "key words," "chaotic." While some artists argued that the cultural industry faced disaster, in spite of the highest audience turnout figures in the last thirty years, others, notably Kwame Kwei-Armah

1 GNM stands for Guardian News and Media (UK), a global news organization that delivers investigative journalism, a trust created to secure financial and editorial independence. 
(the incoming new director of the Young Vic theatre), claimed that theatres in Britain, as opposed to opera, had practised Brexit for a long time (Sierz 2018: 61) and pointed to the insularity of the British stage. Finally, Rufus Norris (artistic director of the National Theatre), called the results a "wake up call," expressing a belief that the arts have become "out of touch" with the real world (qtd. in Hemley 2016) and that a new discussion on what British values and identity consist in was needed; he also suggested that the British theatre had either alienated itself from the people or had been asking the wrong questions.

On reflection, it seems that Norris was not entirely wrong claiming that the British arts sector has become out of touch with the rest of the country. However, the radical diagnosis announced by the director of the most significant political stage in Britain is baffling. As a matter of fact, post-war British theatre can boast a lot of work focusing on the underprivileged, the miserable, the disenfranchised, the "Little Englanders" (Sierz 2018: 68) as well as the racists, in other words, those who apparently voted to Leave the European Union. What is more, these are also plays which enjoyed successful revivals after Brexit, for example Andrea Dunbar's Rita, Sue and Bob Too staged in 2018 or Jim Cartwright's Road revived in August 2017 as well as several revivals of more recent plays whose premieres preceded the Referendum, such as Simon Stephens's Herons (first staged by the Royal Court Upstairs in 2001) revived at the Lyric Hammersmith in January 2016. Herons echoes significantly a list of complaints voiced by the Leavers. It provides a graphic study of a teenage world of physical barbarism in deteriorating educational institutions, a process accompanied by a tangible loss of traditional values visible in the laxity of teachers and the background of broken homes. Further on, Leo Butler's Redundant (Royal Court 2001) addresses the subject of poor working-class people in desperate straits, touching upon the significant and unresolved divisions underlying politics within the UK: middle-class versus working class, young versus old or London versus the rest of the UK. Therefore, the supposed alienation of the British stage does not seem to derive from the writers' lack of concern for the underprivileged. On the other hand, a sense of alienation may derive from the economic exclusion of the poor from much of British "complex culture." In the theatres the problem consists in their absence, with the act of watching performed by a comfortably seated middle-class or liberal audience spying voyeuristically on the poor and the uneducated doing bad things in dilapidated ugly settings, rather than in the

2 The notion of "complex culture" appears in the cultural policy formulated by Tessa Jowell, the Labour Party Culture Secretary. She appoints complex culture, subsidized by the government, as constitutive of national identity and expresses interest in its accessibility (3-9). 
actual appearance of the poor rendered more or less sympathetically on the theatre stages. While the underprivileged are patronized, if not explicitly objectified by the visual regime, the dehumanized spectators delegate the power to act onto the characters "purging themselves" of the flaw, making them capable of and interested in changing the society (Boal 260). What is more, figures quoted by Sierz from the Office of National Statistics point to a twenty-five-percent rise in tickets sold to cultural tourists who expect entertainment, notably viewers from the United States (Sierz 2018: 61). Plays like Simon Stephens's Motortown become a site of "tension between cultural tourism and theatre of protest" (Sierz 2017: 7). And so the story of Danny as an Iraq War veteran, in whose view England is no longer his patriotic homeland and who wants to know the truth about the poor in his own country, blends with the poetics of road movies bringing in scenes of anger reminiscent of Martin Scorsese's Taxi Driver. The audience watches an American film whose main character finds England a foreign country. The dreams of the early activists like Arnold Wesker with his idea of Centre 42 open to the underprivileged or Edward David Berman's initiative of The Ambience Lunch-Hour Theatre Club and Almost-Free Theatre offering one-penny tickets belong to the past.

The purpose of this article is to explore the aims, the effectiveness and, sometimes, the puzzling ineffectiveness of two political theatre projects created in response to the results of the Referendum and the complex situation in the theatre. This includes primarily the feeling that the national stage has failed to notice how divided the citizens have become and to address the growing anger on stage in due time. Each of the projects was launched by a national company-Headlong Theatre Company in co-production with the Guardian and the National Theatre. The idea of both was to stage the outcomes of an extensive investigation of Brexit in order to show and understand what "people in the street think and feel" (Laurie 2017). Considered as interventions triggered by post-Referendum political confusion-and therefore acts of political engagement-both projects emphasise the need of restoring communication within a polarised community whose people "were tired of being lied to" (Laurie 2017). For these reasons, both initiatives were called an exercise in "listening" (GNM 2017; Laurie 2017), projects whose objective was to include a broad spectrum of hitherto marginalized voices from all over Britain. Both initiatives decided to avoid the method of story-telling. The first is a form of interview-based docudrama, a verbatim play written up by Carol Ann Duffy and Rufus Norris for the National Theatre. My Country: A Work in Progress ${ }^{3}$ was premiered on

3 All in-text references to My Country: A Work In Progress by Duffy and Norris will be to My Country. 
February 28, 2017. On March 22 it went on a tour around the UK to reach regional and underprivileged audiences. In November the ввс broadcast a fifty-five minute film adaptation of the play at peak time. The latter project, a small collection of nine online quasi-documentary dramatic monologues addressing an imaginary listener, Brexit Shorts: Dramas from a Divided Nation (2017), was pioneered by Headlong and the Guardian. The testimonies used in verbatim theatre have been replaced with monologues delivered by fictional characters who reveal the "truth" about Brexit by offering a virtual reality. The scripts were written by several authors including Maxine Peake, Abi Morgan, Gary Owen, Charlene James, Meera Syal, Stacey Gregg, James Graham, A. L. Kennedy, and David Hare. The playwrights set the monologues in specific, familiar locations. The monologues appeared online in free access so that the size of the audience can be estimated between 100,000 and 195,000 for each piece. ${ }^{4}$ In 2019 they were screened all over Germany and used as a springboard for discussions on the failure to build communities. Apart from these two projects, there have been several other plays and multiple humorous shows written in reaction to Brexit. For example, Mike Bartlett's nostalgia stricken Albion (2017) is a regular play set in an English garden and partly reminiscent of David Hare's Time to Leave (one of the Brexit shorts) in its use of the garden as a traditional metaphor of national identity. Still, as opposed to Albion, Hare's "short" withdraws sharply from ordering narratives to put emphasis on the Beckettian heap of broken images in the post-Referendum reality. Entertainment capitalized extensively on the discord occasioned by the Eu referendum. Still, while political plays assume engagement (Kritzer 3 ), musical comedies and satires ridiculing famous politicians produce a sense of distance to offer escape from reality rather than serious engagement. Contrary to the discussed projects, they deliberately stay out of touch.

In their response to Brexit, both Headlong and National Theatre decided to rely on variants of the verbatim method. Since 1995 verbatim plays, documentary-styled reports on currently unfolding events, the "headline topics" (GNM 2017), have been used by the British theatres (Kritzer 185), notably in situations of crisis, which demand a radical separation of truth-telling from spin. Hence the decision to use the method must be perceived as relevant: its use informs the audience that the theatre has decided to engage with a significant political or social crisis. The aim of such projects has been to explore "complex issues" and contradictions politicians have been either unable or unwilling to solve.

4 The estimates are based on page entrances on you tube and do not include the early period of release by the Guardian when the visits were not counted. 
And so Hare's famous The Permanent Way (2004), based on hundreds of interviews with victims and rail executives, was written in the aftermath of four train accidents in Britain, a catastrophe perceived as the effect of Thatcher's privatisation of the British Rail. Stuff Happens (2003), also by Hare, written in response to the Iraq War and the international crisis caused by the atrocities in Bagdad, addressed mainly the lies of the politicians and the unclear process of decision-making. Finally, Victoria Brittain and Gillian Slovo weaved together political debate, legal opinion and personal letters to show the rapidly eroding system of democratic values in Guantanamo: Honor Bound to Defend Freedom (2004). A year later Robin Soans wrote Talking to Terrorists (2005). Inspired by a relief worker, the actor and playwright drew a play from stories told by former terrorists whose involvement resulted to a considerable extent from a sense of being totally ignored-from no-one listening. All of the topics surfacing in these crisis-related verbatim plays-including economic and political marginalisation, erosion of a traditionally accepted value systems and the conviction that truth has become elusive-appear also in the contemporary Brexit plays.

The crisis that motivates the use of verbatim in both My Country: A Work in Progress and in the Brexit Shorts series, is not so much related to the decision of leaving the European Union as to the sudden discovery of how deeply the country and its community have been divided and, additionally, how these fissures have been either obscured or ignored by both media and the politicians. In James Charlene's Go Home the young people almost part, divided by the discussion on the results of the vote while in My Country a couple plunges in accusations of racism (My Country 51). A highly emotional reaction is also verbalized by William (representing Caledonia): "And what, you are fucking surprised now that society's fractured apart?" (My Country 31). The lines of conflict formulated in terms of the Referendum question of Leave versus Remain do not seem to address the essential problems that should be diagnosed (for example, distribution of benefits and deindustrialisation). Asked about a crisis of European identity, in the context of The Brexit Shorts, Jess Gormley, the arts and culture commissioning editor, replied that the British were not talking about Europe or the European identity but about themselves (Genova 2019). Indeed, My Country in particular takes the insularity of the British character for granted. The play quotes from David Cameron's "Bloomberg Speech" praising the "island nation" (My Country 15) and declaring its passionate defence, Cameron's famous "Churchill quote" (Wodak 13). Further on, dedicated to the memory of Jo Cox, My Country's intellectual lineage leads to the MPs optimistic opinion that the British society has more in common than that which divides it, an opinion which stands in contrast with the play's research. With the background conviction that 
the UK faces chaos, the essential task of the two projects was primarily to reveal the truth, to "lay the facts bare" and to "remove the mediating hand of creativity" (Lane 60) in a much broader sense than just the aesthetic and the theatrical. The "creativity" David Lane associates with the limitations of dramatic fiction as opposed to verbatim theatre applies also to cultural institutions, politicians and media as producers of fake news and manipulative fictions (My Country 41). Therefore, the feeling that telling stories can no longer contain the crisis refers to more than the convention of a well-made plot. In a recent interview, Tom Stoppard observes that a consistent narrative to accommodate the overflowing chaos is simply impossible, adding that Brexit is too big for the stage (Dickson). Hence, what the theatre may propose is only work in progress. Indeed, the "work in progress" formula is foregrounded in the subtitle of the project submitted by Duffy and Norris.

While the cause-effect formula has been obviously exhausted in its smoothing out of and fictional plotting of reality, Kritzer's more recent concept of political drama as "pragmatic humanism" (219) and a collection of domestic micro-narratives also fails to accommodate the spectrum of conflicts. Both Duffy and Norris promise to show the bare facts. Journalistic reporting on social reality as well as the omnipresent manipulation of facts by politicians to create emotionally charged stories has been perceived as false poststructuralist constructedness (Martin 14) only verbatim methods may overcome. In the context of a "stitched up" reality, a phrase used by Farage in his 2012 Birmingham speech and by Boris Johnson in the play (My Country 32), My Country not only uses, but openly points out the methods and strategies used by verbatim theatre to emphasise the intention of revealing the truth. This includes an increasing distrust of the words spoken by professional politicians- "everybody told lies" (My Country 51, and Time to Leave by David Hare) - and of the images created by the media. Omnipresent infotainment bolsters the perception that the media reporting on Brexit have been taken over by unspecified manipulators and scaremongers (My Country 37) either "punting otherism" (30) or staging political shows with "diva" like celebrities "jeering and laughing" (35). Disillusionment with the regular media and distrust of political "experts" (My Country 31, 51) performing on telly require that the theatre "take on the role of theatre-as-journalism," an opinion voiced a few years earlier by David Edgar (8) and, on another occasion, by David Hare, co-author of the Brexit Shorts (Hummond, Steward 62). Nb in 2005 Harold Pinter spoke bitterly about the "vast tapestry of lies" in his Nobel Speech (3). In an interview with Max Stafford-Clark and Will Hummond, Hare insisted (already in 2008) that because journalism was failing, the theatre simply "rushe[d] to fill that void" (Hammond, Steward 62). However, aspiring to the 
role of a journalist, a historian and a playwright, verbatim theatre-makers run serious risks. They function between the ethical and the aesthetic that guarantees theatrical success and are tempted to blur the distinctions between truth and fiction, an unintended but aesthetically effective manipulation. Christopher Innes's argument that verbatim theatre is simply understood by its audience as "factual" and accurate (442) is somewhat naive and aligns with Hare's declaration that direct address distinguishes cases of people quoted verbatim (Hare Stuff Happens, "Author's Note").

Not unlike much documentary and verbatim theatre, the post-Brexit projects have been made to bring materials otherwise ignored to public attention, to explore the "complex issues" and to set things right. Their ambition was to inform and to educate. Therefore, their moral and ethical claims to truth should not be ignored (Martin 14), although instead of the objective truth they tend to promise, one should perhaps recognize their duty to be honest and to lay bare the facts of their work, especially when building trust becomes their aspiration. My Country explicitly foregrounds the crisis of trust. Britannia (as Government) does not even ask "the people" to trust the government (the experts) any more but to "trust themselves" (31). Hence, for the sake of consistency, the National Theatre's research-based project was launched by amateurs, a poet and a theatre director. Still, the process of collecting material for the archive, one of the gatherers explains, was performed by amateurs trained by a research company. The names of the researchers and the collaborating theatres were publicized-a matter of trust. The idea of the project was to collect data from different parts of Britain. Further assumptions concerning the methods were not revealed and how much mediation has been eliminated or what has remained from the creative process and classified as rejected is not clear. Britannia refers sternly to "witnesses" (6) and to testimonies spoken "verbatim" (7) as if trying to convince the audience that the testimonies are authentic. Verbatim does not use quotation. Instead of quotation marks, the play uses photographs of the interlocutors. Still, in spite of these seemingly strict rules, it is hard to believe that references to Robert Burns or Dylan Thomas come from the interviewees. They must have been provided by the researchers (My Country 41) or inserted by Duffy, so that the communal singing of the "Bread of Heaven" introduces an obviously staged, poetic and solemn quasi-religious atmosphere which does not comply with verbatim theatre.

Though fact-based theatres claim to focus on archival material, i.e. on what really happened rather than providing frameworks or pre-existing points of view, the opening "Arrivals" in My Country do develop a framework. Britannia as "we", a personification of Great Britain with all the required attributes she is 
trying on in an ostentatiously theatrical manner, summons the personifications of regions and actual witnesses in the audience to a hearing to see "what we can learn" (My Country 6). Only later on do the abstractions become specific sources and photographs are flashed out to convince the audience that these are individual testimonies. What overshadows the opening scene is a predefining polarity of centre versus periphery, a division corresponding to the results of the vote yet to come. This essential polarity becomes the basis of a further selection that has not been openly declared. London stands for Westminster while the difference between the leaders of major political parties and the governments in London and in Brussels have been entirely obliterated. More importantly, London's multilingual population has been excluded, hence a project whose aim was to be inclusive introduces a form of selection that excludes a large part of the community. What has been selected from the archive defines the project's point of view and invokes a preferred reading. Drama, after all, narrates by showing (Chatman 113) and by "an extradiegetic 'superordinate narrative system,' which selects, arranges, and focalises the story material" (Weidle 76). If trust is to be restored in the course of a verbatim project, this superordinate narrative system, i.e. the grounds of the selection must be known.

In the case of My Country, the superordinate narrative system, its point of view and its "preferred reading" can be traced back to the public dedication of the project to Jo Cox. Posthumously honoured with a heraldic shield whose motto says "More in common," the dedicatee brings back the memory of her well-known statement that "We are far more united and have more in common than that which divides us" (Cox 2015). While the heraldic motto refers traditionally to the chivalric code, in the case of the assassinated MP, it derives from her political program, which grants My Country's narrative system a definite point of view. In theatrical terms, public dedications-forms of demonstration, ostentation and exhibition-are performative acts par excellence as they constitute "the act they are supposed to describe" (Genette 134). The dedicatee in turn, as Gérard Genette argues, "is always in some way responsible for the work" and becomes its auctor (136). Hence, the dedication reveals that the project has political affiliations, a fact which undermines its credibility as a verbatim play that, based on independent research, shows what has actually happened. As if following in the footsteps of the diseased politician, Britannia summons the regions to a carefully staged meeting where the listeners are initially in the audience, not on stage. Only later, in the course of the increasing chaos, are the personifications of central and local governments and, ultimately, everybody involved asked to listen to the multiplying interlocutors (My Country 31). Even in the face of this growing complexity and multiple divisions, Britannia 
insists rather unrealistically on unity and on what people have in common ( $M y$ Country 31) as if reflecting Cox's motto. In theatrical terms, the performativity of the hearing (an analogue of the listening exercise) called "The Sacrament of Listening" (My Country 11) is evident. Britannia tries on her gear, selects the right music and lighting (My Country 3) while the room is "sorted" to provide a setting. The choice of setting, as opposed to some diversity of language accents, eliminates the specific and the local by focusing on an empty school hall transformed into a polling station where delegates sit behind exam desks, which turns them into students. "The Sacrament of Listening" itself appears to be a ritual enhancing the effect of an aesthetically and politically motivated performance but it may also refer to a religious concept which perceives reality as sacramental, meaning, reality itself-no matter how diverse and divided it seems to us-points to God who is within us, beyond and with us. If so, listening is not a strategy but a "sacramental space" where people "in the self-offering gift ... enable each other to listen and serve as [they] have been heard and saved" (Ford 106). The self-offering gift may concern Cox and her sacrifice. In the light of these quasi-religious amalgamating concepts of an imaginary people, the multiple divided communities become merely an illusion Britannia (as Farage) diagnoses as disconnected from politicians but not from politics (My Country 36). Britannia as personification of Britain creates a poetic unity weaving together a nostalgic litany of historical events concluded with easily recognisable excerpts from Cox's speech (My Country 38-39).

In accordance with verbatim requirements, My Country avoids the cause-effect logic and its fictionalising effects but mediates, via succession and chronology, a stream of utterances in which actors-filters, a relatively small team, are responsible for a myriad of voices. Personifications of both central and regional government and the individual testimonies of named interviewees (as well as "quotations" from political speeches) are delivered by the same actors. Britannia, apart from her allegorical function, amalgamates the voices of several political centres including the Government, David Cameron, Boris Johnson, Nigel Farage, Jeremy Corbyn and Theresa May. The "regions" deliver also a collection of individual male and female voices. Although Duffy and Norris declare the intention of reporting verbatim what people think, their creative mediation is noticeable. Though presumably necessary for aesthetic reasons, it interferes significantly with the findings of the researchers. The play subdivided into twelve parts with distinct opening and closing segments- "Arrivals" and "The Leave-taking"becomes indicative of a meaningful sequence, a journey that starts in the past. The nostalgic six "Arias" sung by the regions indulge in heritage nostalgia beautifying the past in spite of its obvious deficiencies, an attitude resulting 
from an inability to cope with change in general and specifically in the spheres of education, agriculture, loss of traditional values, distribution of benefits, immigration and economy. As a result, the truly verbatim material following the operatic introduction must be literally announced as "people's words" (My Country 15). The subsequent parts of the "voices" converge around a selection of topics including Europe, patriotism, hardship, immigration and leadership moving towards the vote and its aftermath. There is neither an obvious climax nor a turning point. Indeed, the vote does not change the fate of the collective "protagonist" as the problems remain unsolved. On the other hand, the "Feast" lays down unreal prospects for the future verbalised by Boris Johnson as "the sunlit land beyond" (My Country 34), an otherworldly vision of New Jerusalem taken from John Bunyan's Pilgrim's Progress. What is needed, the play suggests, is a messiah, "fresh" leadership (My Country 52), be it "a benign dictator" (56) as South-West (Jane) proposes leaving the "facts of life" behind.

Lending the stage of the National Theatre to the "silent majority," Norris and Duffy, not unlike populist leaders, enunciate attitudes that have not reached a level of explicitness as "collectively shared" (Krämer 67), such as "the people," "the nation" or "fresh leadership." As if following Cas Mudde's definition of populism, they "consider the society to be ... separated into two homogeneous and antagonistic groups, 'the pure people' versus 'the corrupt elite"' (2004: 543), the regions versus the centre. The regions as a collective, the "pure people," become an "empty signifier" turned into "an instrument for the construction of relations of equivalence and frontiers of difference" (Finlayson 2013: 198). The House of Commons amalgamating all parties (impersonated by Britannia) becomes an expensive whisky bar (My Country 34), a distant elite whose expenditures are exorbitant (17), a seat of corruption (37) whose "invertebrate jellies" (36) and "Backhanders" (37) "sold Britain down the river" (33). The purity of the people homogenises in the process of othering. Victims of badly governed institutions, e.g. NHS, education and social services (25-26); threatened by uncontrollable immigration (Britannia as Farage, My Country 23); disciplined by the stereotypically interpreted regulations of the European Super State $(16,17)$ and political correctness, the "people" emerge from the vote victoriously as "real," "ordinary" and "decent" (Britannia as Farage, $M y$ Country 49). These decent unorganized followers, in line with populist political strategies (Weyland 14) offer unmediated and direct support to personalistic leaders performing the roles of amateur politicians, vide Farage, and types of an "everyman."

Due to their formal simplicity, Brexit Shorts avoid the framing mediation of My Country, a decision which eliminates the superordinate narrative system 
with its ideological or political presumptions, focalisation and preferred reading. The collection consists of an open series of nine five-minute dramatic monologues-each written independently-imitating the direct address used by verbatim theatre. Creating their own fictitious characters instead of "real people," the videos produce a virtual reality. The order of watching depends on the viewer's choice, a participation enhancing method which invites the viewers rather than politicians to co-author as it is the viewer that decides about chronology and in that way produces his own narrative. The aim of the series Jeremy Herrin, the Artistic Director of Headlong, declared was to explore the complexity and diversity of opinion "to embrace the contradictions" but, additionally, to "move the conversation forward" (GNM 2017). Therefore, as opposed to My Country, the prevalent mode is gently interrogative, less emotional and more empathetic, inviting the imaginary interlocutor or interviewer to a conversation in an almost romantic Hazlittean sense of an exchange between social equals. The interlocutors invited to a conversation are the viewers (an individualised audience), although in Permanent Sunshine (written by A. L. Kennedy) they seem to be predefined as English. The monologue, at a linguistic level, a running tacit play of words, points out what the English stereotypically expect from a young male urban Scot-swear-words. However, the protagonist does not attack the interlocutor but acknowledges the English stereotypes and attempts to overcome them, not by passivity or by argumentative denial but by combative conversational wit and charm. This "positive" trajectory of the short film goes into the direction of euphoria, away from the otherwise pervasive mode of irony. The title of the play, recalled at the end, becomes an escape into optimism slightly reminiscent of "the sunlit land beyond" from $M y$ Country but avoids any connections with populism. In Brexit Shorts anger and fear tend to give in to a reflective mood, notably in Just a T-shirt (written by Meera Syal) and Time to Leave (David Hare). Brexit Shorts become an invitation extended to the ordinary people seated outside the theatre house and produce effectively space for a conversation, that Trilling would associate with a mode of communication based on sincerity, inviting "congruence of avowal and actual feeling" (4), which provides an opportunity for reconciliation.

The change of medium renders Brexit Shorts more accessible by offering a democratic alternative to the regular political theatre. What is more, the medium enables the producers to shoot the scenes in real every day locations familiar to the audience rather than on stage, in an aesthetically pre-constructed uniform set. The locations in Brexit Shorts include the Greater Manchester Law Centre (Shattered by Maxine Peake), Northern Ireland's peace-line (Your Ma's a Hard Brexit by Stacey Gregg), a farm in Wales (Pines by Gary Owen), 
The Station Cafe near Wigan North Western (Go Home Charlene James), the Wolverhampton Central Police station (Just a T-shirt), internet virtual reality (Burn by James Graham) as well as a sitting room (The End by Abi Morgan) and a garden (Time to Leave by David Hare). In Permanent Sunshine the location is central Glasgow with the actor gradually approaching George Square, moving with his interlocutor further via Virginia Square and then Royal Exchange Square where he walks past the Gallery of Modern Art. The actor (Scott Reid) would be known to Scottish viewers of film and Tv. The character he represents evidently comes from a poor area of the city; Linkwood Avenue (where "his father" died) is on the periphery of the city. With strong emphasis on realism and diversity, the centre vs region polarity (almost synonymous with Leave vs Remain), even if it exists in the background of the videos, does not result in pitting one group against the other. On the contrary, the imagined polarities as well as occasionally quoted slogans and stereotypes, such as "taking back control" or negative stereotypes about various others (the "Scum" in Go Home), are either undermined or foregrounded as unfair. Post-Referendum chaos and anger are either inspired by "warriors," like the lady-troll in Burn, or result from a disappointment with the situation after the Referendum metaphorically represented as a divorce after 43 years of marriage (The End). In Time to Leave, located in an English garden, the conservative owner admits ironically that voting Leave was a mistake-they wanted to leave England rather than the European Union. Finally, rather than expose the conflicts and perceive the nation as irreversibly divided, Brexit Shorts focus on conversation and understanding. Go Home in particular, develops a story of reconciliation between two young people staged against the background of the "up north" vs London polarity to embrace the contradictions and move forward.

The two projects, My Country and Brexit Shorts, written in the aftermath of the Referendum, bring to life the questions raised on both sides of the voting divide. Written in response to the queries about the political engagement of the artistic institutions and their ability to address the current crisis, both become involved in field research and in the selection of an appropriate form of political drama to embrace the situation. Both Headlong and the National Theatre reject the earlier story-telling drama as inefficient to focus on docudrama based on verbatim methods. In that way, they recognize that the current situation in Britain takes the form of a crisis comparable with the war in Iraq or terrorism - the post-vote divide exceeds the accepted standards of a polarised and oppositional political culture, while the conviction that people are lied to and ignored dismantles democratic engagement. Responding to the communication crisis, the projects become variously organised exercises in listening. Although 
the National Theatre employs a group of trained field researchers, it presupposes polarities and excludes a large part of the Remain voters. Additionally, the diverse frameworks introduced for aesthetic purposes have a dangerously amalgamating effect prioritising seemingly contradictory readings. Labour Party and Nigel Farage find a common ground in the hypostasis of the "people." Paradoxically, "my" country transforms into "our" country, as in Timberlake Wartenbaker's postcolonial nation-building story. On the other hand, Brexit Shorts withdraws successfully from any forms of tangible extradiegetic narrative control, a strategy which enhances the process of exploration, analysis and conversational relationships within the community. Both projects remain formally open, indicating that their statements are in medias res and, therefore, "works in progress."

\section{| Works Cited}

Boal, Augusto. "Poetics of the Oppressed." Modern Theories of Drama. A Selection of Writing on Drama and Theatre, 1840-1990. Ed. George W. Brandt. Clarendon Press, 1998. 254-260.

Chatman, Seymour. Coming To Terms: The Rhetoric of Narrative Fiction and Film. Ithaca: Cornell University Press, 1990.

Cox, Jo. “Devolution and Growth Across Britain.” Volume 596. Wednesday 3 June 2015. UK Parliament. https://tinyurl.com/tn44egnh. Accessed 27 June 2017.

Dickson, Andrew. “Tom Stoppard: Brexit is Too Big for the Stage." The Guardian 10 February 2017. https://tinyurl.com/3zefrxwe. Accessed 19 June 2017.

Duffy, Carol Ann, Rufus Norris. My Country: Work in Progress. London: Faber and Faber, 2018.

Edgar, David. "A Hard Time for British Plays: David Edgar Defends the Vibrancy of British Playwriting." Hard Times 91 (2012): 7-12.

Finlayson, Alexander. "Ideology and Political Rhetoric." The Oxford Handbook of Political Ideologies. Eds. Freeden, M., Sargent, L. T. and M. Stears. Oxford: Oxford University Press. 2013. 197-213.

Ford, Leighton. "Listening." Lifelong Leadership: Woven Together through Mentoring Community. Ed. Mary Kate Morse. Colorado Springs: NavPress, 2020. 95-112.

Genette, Gérard. Paratexts: Thresholds of Interpretation. Cambridge: Cambridge University Press, [1997] 2001.

Genova, Alexandra. Conversations and Film Screening at Goethe Institut: Dramas from a Divided Europe. 2019. Accessed 12 Dec. 2020. 
GNM press office. "The Guardian and Headlong present Brexit Shorts:

Dramas from a Divided Nation." The Guardian 19 June 2017. https://tinyurl.com/5pudpydc. Accessed 20 June 2017.

Graham, James. “Burn.” (Brexit Shorts). The Guardian 26 June 2017. Accessed 28 June 2017.

Gregg, Stacey. "Your Ma's a Hard Brexit." (Brexit Shorts). The Guardian 19 June 2017. Accessed 25 June 2017.

Hammond, Will, and Dan Steward. Verbatim, Verbatim: Contemporary Documentary Theatre. London: Oberon Books, 2008.

Hare, David. “Time to Leave." (Brexit Shorts). The Guardian 19 June 2017. Accessed 25 June 2017.

---. Stuff Happens. London: Faber and Faber, 2005.

Hemley, Matthew. "Rufus Norris Says the Arts Are 'Out of Touch.” The Stage, 26 July 2016. https://www.thestage.co.uk/news/rufus-norris-says-the-arts-are-out-of-touch. Accessed 27 June 2017.

Innes, Christopher. “Towards a Post-Millennial Mainstream? Documents of the Times." Modern Drama 50.3 (2007): 435-452. Project Muse, doi:10.1353/mdr.2007.0055.

James, Charlene. "Go Home." (Brexit Shorts). The Guardian 19 June 2017. Accessed 25 June 2017.

Jowell, Tessa. "Government and the Value of Culture." 2004. 1-19. Shiftyparadigms.org. Accessed 2 June 2014.

Kennedy, A. L. "Permanent Sunshine." (Brexit Shorts). The Guardian 19 June 2017. Accessed 25 June 2017.

Krämer, Benjamin. "Media Populism: A Conceptual Clarification and Some Theses on Its Effects." Communication Theory 24:1 (2014): 42-60.

Kritzer, Amelia Howe. Political Theatre in Post-Thatcher Britain. New Writing: 1995-2005. New York: Palgrave Macmillan, 2008.

Lane, David. Contemporary British Drama. Edinburgh: Edinburgh University Press, 2010.

Laurie, Campbell. "How They Created the NT’s Brexit Play My Country." WhatsOnStage. 10 March 2017, https://tinyurl.com/y9p323ay. Accessed 27 July 2017.

Martin, Carol. “Bodies of Evidence.” TDR: The Drama Review 50:3. 2006: 8-15. JSTOR, www.jstor.org/stable/4492691.

Morgan, Abi. “The End.” (Brexit Shorts). The Guardian 26 June 2017. Accessed 28 June 2017.

Mudde, Cas. "The Populist Zeitgeist." Government and Opposition 39:4. 2004: 542-563.

Owen, Gary. “The Pines." (Brexit Shorts). The Guardian 26 June 2017. Accessed 28 June 2017. 
Peake, Maxine. “Shattered." (Brexit Shorts). The Guardian 26 June 2017. Accessed 28 June 2017.

Pinter, Harold. "Harold Pinter: Art, Truth \& Politics”. Nobel Lecture, December 7, 2005.

Sierz, Alex. "British Theatre after Brexit: One Year On." A Journal of Performance and Art 120 (2018): 60-70.

---. "Dark Times: British Theatre after Brexit." A Journal of Performance and Art 115 (2017): 3-11.

Syal, Meera. "Just a T-Shirt." (Brexit Shorts). The Guardian 19 June 2017. Accessed 25 June 2017.

Trilling, Lionel. Sincerity and Authenticity. Cambridge, MA: Harvard UP, 1972. Weidle, Roland. "Mimetic Narration: Documentary Theatre and the Staging of Truth." Narrative in Drama. Eds. Merle Tönnies and Christina Flotmann. Trier: WVT, 2011. 73-94.

Weyland, Kurt. "Clarifying a Contested Concept: Populism in the Study of Latin American Politics." Comparative Politics 34.1 (2001): 1-22

Wodak, Ruth. "We have the Character of an Island Nation.' A Discourse-Historical Analysis of David Cameron's 'Bloomberg Speech' on the European Union.” EUI Working Paper RSCAS 36 (2016): 1-25.

\section{| Abstract}

EWA KĘBŁOWSKa-ŁaWNiCZaK

\section{Brexit on Stage: Two Verbatim Projects in Progress}

The article deals with two post-Referendum projects launched by British national organizations, the National Theatre and the Guardian with Headlong, whose task was to reflect more accurately on a broader range of current British experience. The projects were written in response to questions on whether national artistic institutions, the subsidized "complex culture," have not been out of touch with the rest of the country, notably the post-Referendum crisis. Both projects set out to research the crisis with documentary and quasi-documentary methods, to involve in an exercise in "listening" and to focus on polarisation, voter fatigue and lack of trust. The article concentrates on the two projects as variants of political theatre and on the ways they use the verbatim method in their attempts to diagnose and understand the crisis arguing, further on, that the effects differ, leading either to populism or to empathetic understanding and reconciliation.

Keywords: Brexit; Brexit Shorts; political theatre; verbatim; populism; reconciliation 


\section{| Abstrakt \\ EWA KęBŁOWSKA-ŁAWNiCZAK \\ Brexit na scenie: dwa otwarte projekty verbatim}

Artykuł poświęcony jest analizie dwóch projektów teatralnych zrealizowanych pod auspicjami instytucji narodowych - Teatru Narodowego oraz „Guardiana” we współpracy z zespołem Headlong. Celem projektodawców była analiza aktualnej sytuacji społecznej w Wielkiej Brytanii po referendum, a projekty powstały w odpowiedzi na zarzuty dotyczące utraty więzi ze społeczeństwem. Obie inicjatywy oparto na metodach stosowanych przez „teatr na faktach”, przyjmując z różną konsekwencją metody badań terenowych i tworząc archiwa wypowiedzi. Badano głównie polaryzację oraz brak zaufania społecznego. Artykuł skupia się na analizie zróżnicowanych efektów, jakie obserwujemy w Brexit Shorts oraz My Country. Efekty te, znacząco różne, prowadzą ku próbie zarówno społecznego pojednania, jak i niezamierzonego lecz wyraźnego populizmu.

Słowa kluczowe: Brexit Shorts; brexit; teatr polityczny; teatr na faktach;

populizm; pojednanie

\section{| About the Author}

Ewa Kębłowska-Ławniczak is Professor of English Literature and Comparative Studies at the University of Wrocław, Poland. Her research interests include the exploration of intersections between visuality and literature; life writing and adaptation in paratext. She is the author of the Visual Seen and Unseen: Insights into Tom Stoppard's Art (2004), From Concept-City to City Experience (2013), "Adaptations of Visual Material: Paintings, Drawings and Maps" (2009), “The Exhibited in the Order of Exhibition: Adaptations for the Stage" (2010). Her recent publications include "The Loss Library and Other Unfinished Stories: Towards a Collection of Creative Paratextual Writing or Literature in potenta" (English Studies in Africa 2020), "Liminal hypotext-hypertext relations in selected Shakespearean prequels, sequels and gap-fillers" (Journal of Adaptation in film and Performance 2021) and "Adaptation in Poland: A paradigm shift" (Journal of Adaptation in film and Performance 2021). E-mail: ewa.keblowska-lawniczak@uwr.edu.pl ORCID: 0000-0003-2708-1552 